\title{
オキサトミドによるスギ花粉症初期治療
}

一最善の投与開始時期，投与期間についての検討一

\begin{tabular}{|c|c|c|c|c|c|}
\hline 越 & 文和 ${ }^{1)} \cdot$ 出島 & 健司 ${ }^{1)}$ - 竹中 & 洋1) & ·齊藤 & 憲治11 \\
\hline & 了1) • 高木 & 伸夫1) - 安田 & 範夫 & - 村上 & \\
\hline & 秀樹2) - 日向 & 美知2) - 立本 & 圭吾2) & ·任 & 書喜2) \\
\hline & 渉3) • 寺薗 & 富朗 ${ }^{3)} \cdot$ 日向 & 誠3) & · 松本 & 吏子3) \\
\hline & 永祐 ${ }^{3)} \cdot$ 土井 & 玲子 3$) \cdot$ 三牧 & 三郎4) & ·西嶋 & 信雄4) \\
\hline & 千久 ${ }^{4)}$ - 伊達 & 敬一5) • 園田 & 隆朗5) & - 大梘 & 晃直6) \\
\hline & 隆保6) • 八木 & 正人7) - 中井 & 茂8) & - 昌子 & \\
\hline & 健司10) & & & & \\
\hline
\end{tabular}

\section{Evaluation of Initial Treatment with Oxatomide on Japanese Cedar Pollinosis}

\author{
Fumikazu Mizukoshi, Kenzi Dezima and Hiroshi Takenaka \\ (Kyoto Prefectural University of Medicine), et al
}

The effect of Oxatomide in the initial treatment of Japanese cedar pollinosis was examined in 11 facilities in Kyoto prefecture. This study examined the most appropriate starting time and period of administration for the highest effect of the initial treatment.

The following results were confirmed by administrering Oxatomide during the initial treatment for Japanese cedar pollinosis on 1991. The effect of Oxatomide was obtained after administering for one week or more, including the highest effect after two weeks for sneezing and three weeks for nasal discharge. However, no effect on sniffling. These results suggest that two to three weeks is the best administration period for Oxatomide in the treatment of Japanese cedar pollinosis.

In addition, a close relation between pollen information facilities and practical medicine in the region, is necessary for the initial treatment of pollinosis.

Key words : Oxatomide, Initial treatment, Japanese Cedar pollinosis

\section{はじめに}

スギ花粉症に対して飛散早期より薬物治療を開始し, 本格的な花粉飛散開始時の症状緩和をはかる初期治療が， 近年提唱されている.すでに種々の薬剤で検討が行われ，
その効果が報告されている．しかしながら実地臨床の場 でつねに問題となるのは, この初期治療を予測される本 格的花粉飛散日に対し，どの時点から投薬を開始するの が最も効果的かといら，服用開始時期設定の問題かと思
1) 京都府立医科大学
3）京都第二赤十字病院
5）済生会京都府病院
7）舞鶴赤十字病院
9）公立南丹病院
11）明治鍼炎大学附属病院
2）京都第一赤十字病院
4）京都市立病院
6) 国立舞鶴病院
8) 国立福知山病院
10）愛生会山科病院 
われる. 今回我々は，この服用開始時期に関するいくつ かの問題を解明する一助として，ケミカルメディェー ター遊離抑制剂オキサトミド錠を用いて，スギ花粉症初 期治療に関して，1)本格的飛散開始日前のどの時点ま でに投与を開始すべきかといら，最少有効投与開始日と， 2 ) 投与期間をどこまでさかのぼって延長する意義があ るかといら, 最大有効投与期間の 2 点について検討を加 艺若干の知見を得たので報告する.

\section{対 象}

1991年 1 月末から 3 月にかけて京都府立医科大学, 京 都第一赤十字病院, 京都第二赤十字病院, 京都市立病院, 愛生会山科病院の京都市内 5 施設ならびに, 国立舞鶴病 院, 舞鶴赤十字病院, 国立福知山病院, 公立南丹病院, 済生会京都府病院，明治鍼众大学附属病院の京都府下 6 施設, 計11施設で今回の検討がなされた。これらの施設 で前年度までにスギ花粉症の確定診断されている，15歳 以上の患者で, 後述する除外項目に該当しない者を対象 とした．さらに飛散初期から投薬を開始するに際しては， その意義を口頭で説明し同意の得られた患者とした。効 果判定に足る症状記載のない症例や解析対象期間の薬剤 服用率が $60 \%$ に達しない症例は除外した結果, 最終的な 解析対象数は男性36名, 女性129名, 計165名であった。

除外規定は以下の通りである.

1 ) 効果判定の妨げとなる程度の鼻疾患(慢性副鼻腔 炎, 肥厚性鼻炎, 鼻中隔湾曲症等)を合併する患者.

2 ) 効果判定に影響を及ぼす可能性のある以下の薬剤 で, 持続使用が避けられない患者(抗ヒスタミン剤, DSCG 点鼻剤, オキサトミド以外の抗アレルギー剤, ヒスタミン加 ケグロブリン製剤, 局所ステロイド剤, ロー ウォルフィア系抗圧剤, 市販点鼻薬を含む局所血管収縮 剤など)。

3 ）重症の喘息, 気管支抎張症の患者.

4 ) 減感作療法中の患者 (但し, 減感作療法開始半年 以上経過し維持療法中の者は除外しない).

5 ）妊娠および妊娠の可能性のある患者. 授乳中の患 者.

6）眠気を催すことがあるので，運転や危険を伴う機 械の操作に従事する患者.

7 ）その他, 医師が本試験に不適当と判断した患者.

\section{方 法}

投与方法は，オキサトミド剂(セルテクト錠) $30 \mathrm{mg}$ 錠を常法用量に従い1 日 2 回, 朝および就寝前に服用す ることを原則とした．投与開始時日については，本検討 の主旨からも本格的な花粉飛散 3 週間以上前が好ましい と考光, 同年 1 月中旬までのスギ標準木観察や気象状況 等から，2月 1 日と決定した。オキサトミド剤の服用開 始より, 臨床症状の記載とアレルギー日記による症状記 録を開始した。オキサトミド剤服用中に除外規定に含ま れる併用剤を必要とした場合は，その時点で本検討を中 止した. 期間中にオキサトミド剤に関連すると推測され る副作用が出現する等, 主治医が必要と判断した症例に は血液一般, 血液生化学, 尿一般検查等を適宜実施する こととした。

\section{スギ花粉飛散状況}

スギ花粉数の観測には, 本検討参加施設 (未設置 3 施 設を除く)に設置されたダーラム型花粉捕集器を用い, 1 平方 $\mathrm{cm}$ あたり 24 時間の落下花粉を記録した. 1991年 の京都府下 8 施設の飛散状況を, 地域別に 2 分して図 1 ， 2 に示す. 後述する効果判定には, シーズン前半のいく つかの大きな飛散日を起点として, 症例を群別する必要 がある. 詳細は考案にて後述するが, 今回の参加各施設 の位置する京都府下全域では, シーズン初期の飛散パ ターンは一致するため, 京都府立医科大学での観測結果 をもってこれを決定した．図 3 に示すごとく同年の第 1 花粉観測日は 2 月 5 日(京都府立医科大学)であり, 本格 的飛散開始日は 3 月 5 日, これに続く花粉飛散の第 1 は 3 月 7 日, 第 2 ピークは 3 月13日であった。このピーク の基準についても考案で後述する.

\section{効果判定}

本検討はスギ花粉症初期治療にオキサトミド剤を用い た場合の，最善の投与開始時期を検討することに主眼を 扣いた．本格的飛散開始日前のどの時点までに投与を開 始すべきかといら最少有効投与開始日と, 投与期間をど こまでさかのぼって延長する意義があるかといら最大有 効投与期間の 2 項目について検討するには，本格的花粉 飛散開始日である 3 月 5 日を起点とし, 週単位でこれを さかのぼって患者グループを分け, 第 1 ピーク日, 第 2 ピーク日に拈ける各群の自覚症状スコアの統計学的有意 差を検定する方法をとった。 


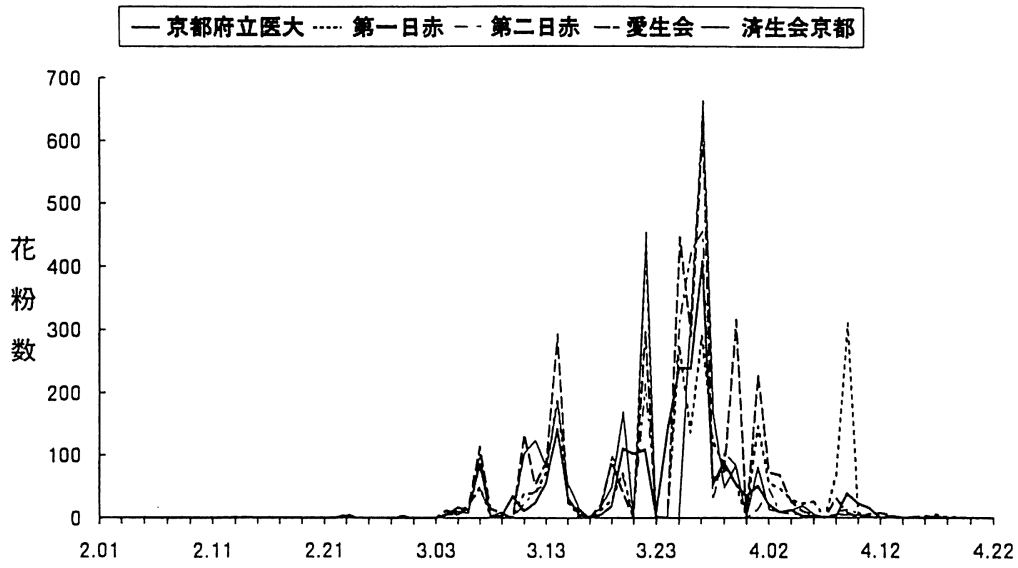

図 11991 年スギ花粉状況(京都市扰よび府南部)

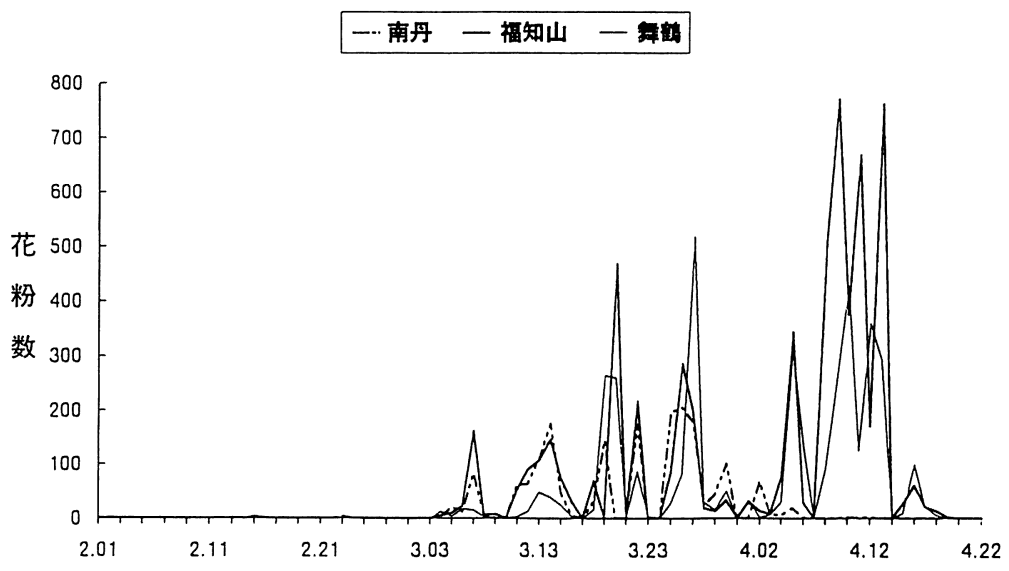

図 2 1991年スギ花粉状況(京都府北部)

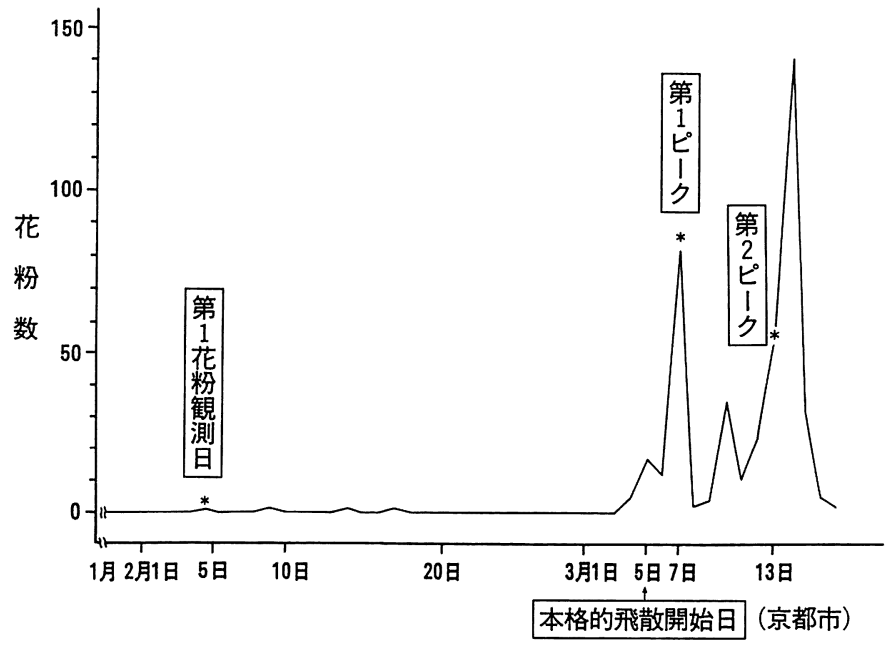

図 3 1991年前半のスギ花粉飛散 
1 . 最少有効投与開始日の検討：

本格的飛散開始日の前いつまでに投与を開始していれ ば，本格的飛散開始後に服用を開始した患者に対して， 有意な症状抑制が得られるかといら検討である. 図 4 に 示すごとく， 3 月 5 日を起点とし 1 週間さかのぼった 2 月27日までに投与を開始し第 1 ピーク，第 2 ピーク以降 まで服薬を続けていた者を 1 週群とした。同様に本格的 飛散開始日の 3 月 5 日を 2 週間さかのぼった 2 月20日以 前に投与開始していた者を 2 週群とし，以下同様に 2 月

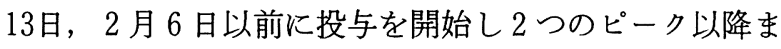

で服薬を続けていた者を 3 週群，4 週群とした．本格的 な花粉飛散が始まった 3 月 5 日以降に来院し，オキサ卜 ミド剤投与を始めた患者群を対照群として，2つの飛散 ピーク日の鼻症状スコア(全般的鼻症状)を群間で比較検 討した。

2. 最大有効投与期間の検討 :

本格的飛散開始日の前どこまでさかのぼって服用期間 を延長する意義があるかについての検討である. 図 5 に 示すごとく 3 月 5 日を起点として，1 週間ごとにさかの ぼる 2 月 27 日， 2 月 20 日， 2 月 13 日， 2 月 6 日の 5 時点

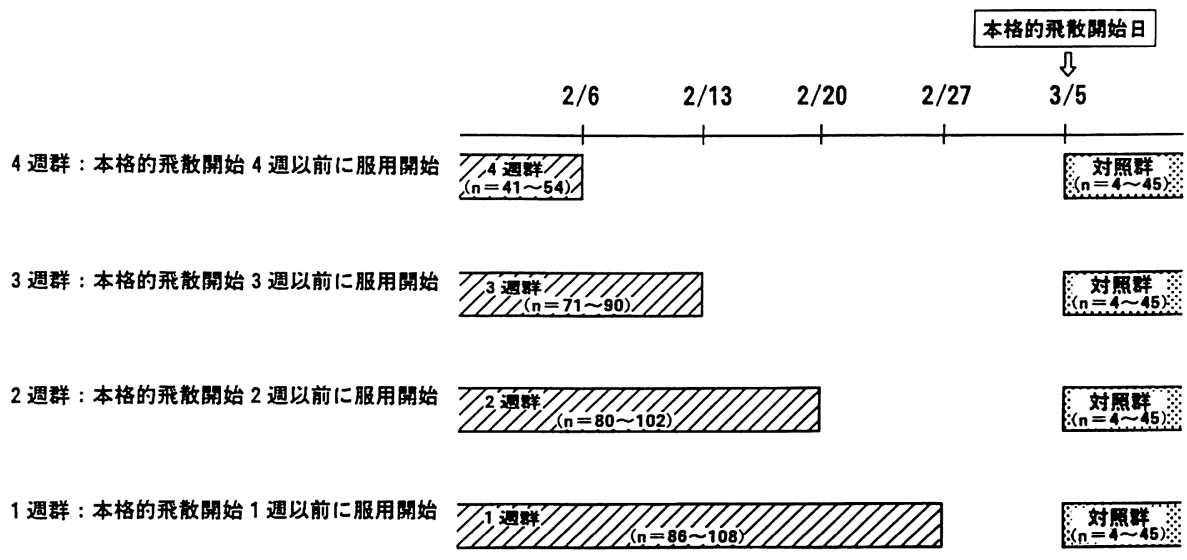

図 4 最小有効投与開始日の検討

一各群のグループ分けー

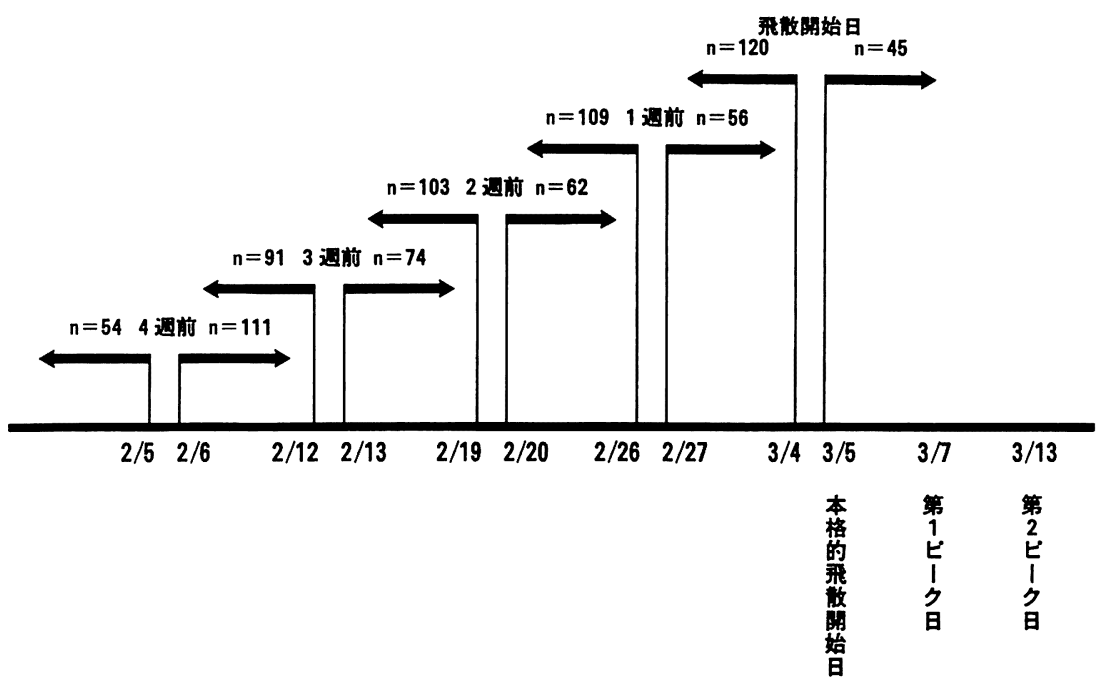

図 5 最大有効投与期間の検討 一各群のグループ分けー 
で前後に二分し分割した両群の第 1 , 第 2 飛散ピーク日 に扣ける鼻症状スコア（全般的鼻症状，〈しゃみ，鼻水， 鼻閉)を統計学的に検討した。

\section{結 果}

1 . 最少有効投与開始日の検討結果 :

図 4 亿示した 4 群の内, 今回の検討中もっとも早い時 期から投与を開始した 4 週群と，本格的飛散開始後より 投与を始めた対照群の全般的鼻症状スコアの推移を図 6 に示し，これを例にとって説明する. 四中に本格的飛散 開始 4 週間前から，オキサトミド服用を続けていた群の スコア変動を○で, 対照群を $\triangle$ で示す. 花粉数の増加に
相関し両群の鼻症状スコアが上昇するが，オキサトミド 服用群が緩徐である. 先に決めた効果判定日である第 1 第 2 飛散ピーク 3 月 7 日， 3 月 13 日の全般的鼻症状スコ ア点数を有意差検定してみると，第 1 飛散ピークで $5 \%$ 以下, 第 2 飛散ピークで $1 \%$ 以下の危険率で有意差が得 られた. 同様の検討を 3 週群, 2 週群, 1 週群で行った ものを図 $7 \sim 9$ に示す. 服用期間が 3 週以下の 3 群はす べて第 1 , 第 2 ピークの全般的鼻症状が $1 \%$ 以下の危険 率で対照群に対し有意に低く抑制されていた。

2 . 最大有効投与期間の検討結果 :

本格的な花粉飛散日を 1 週ごとにさかのぼった 5 つの 時点で, 前後に分割した 2 群の全般的鼻症状スュアの分

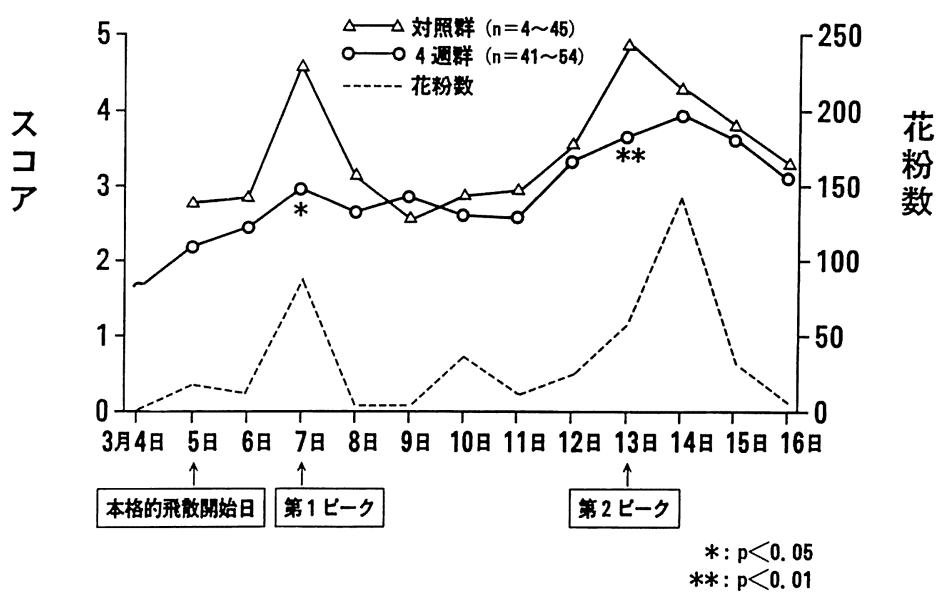

図 6 全般的鼻症状 4 週群と対照群の比較

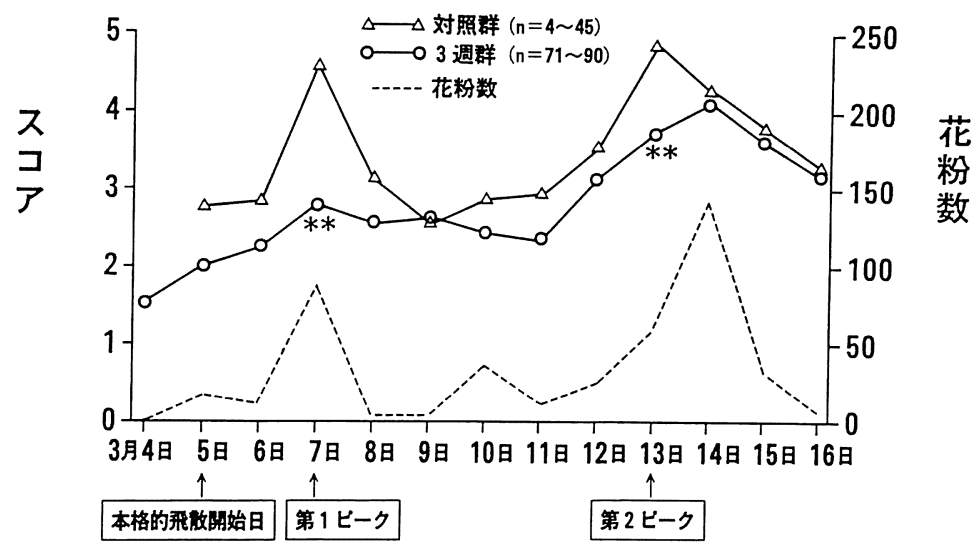

図 7 全般的鼻症状 3 週群と対照群の比較 
布の実際と, 第 1 飛散ピーク日での 2 群間のスコア平均 の差，ならびに有意差検定を示したのが図10である．例 えば 3 月 5 日で分割したスュア平均差は, 初期治療を受 けた全症例と飛散開始後に来院した対象群との比較にな り当然スコア平均差も大きく，2群間に $1 \%$ 以下の危険 率で有意差が認められる．これを 1 週間さかのぼった 2 月27日のスコア平均差は本格的花粉飛散 1 週間以内の才 キサトミド投与群と，それ以前に投与を始めた症例の比 較となる。ここでも投与期間の長い群に有意の症状抑制 が得られたこととなる。この有意差はさらに 1 週さかの ぼった 2 月20日までは見られたが，3 週間さかのぼった
2 月 13 日では比較対照となる分割日以降投与群も， 3 週 間のオキサトミド服用期間があり，両群に症状抑制の有 意差は見られなくなった。くしゃみについては 2 週間前 まで(図11)，鼻水では 3 週間前まで投与期間を延ばして も有意に症状が抑制されていたが(図12)，鼻閉について は全期間を通じて有意な差は認められなかった(図13). 同様の検討法で第 2 ピーク日についてみると，全般的鼻 症状は 2 週間(図14), くしゃみは 1 週間(図15), 鼻水は 3 週間の投与延長で症状を軽症化したが(図16)，鼻閉は ここでも投与期間による有意差は見出せなかった（図 17)。これらの結果の総括を表 1 と示す.

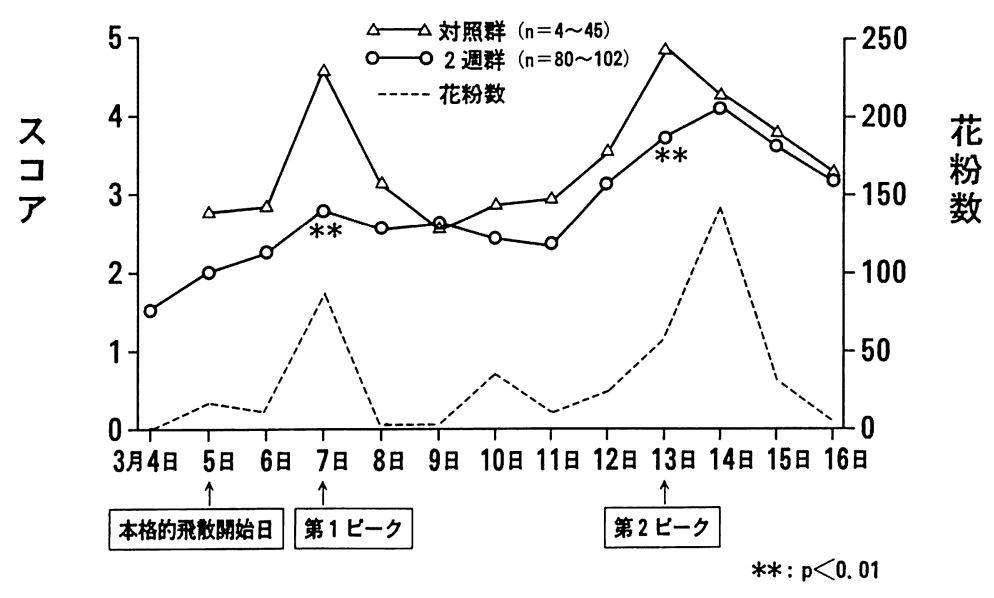

図 8 全般的鼻症状

2 週群と対照群の比較

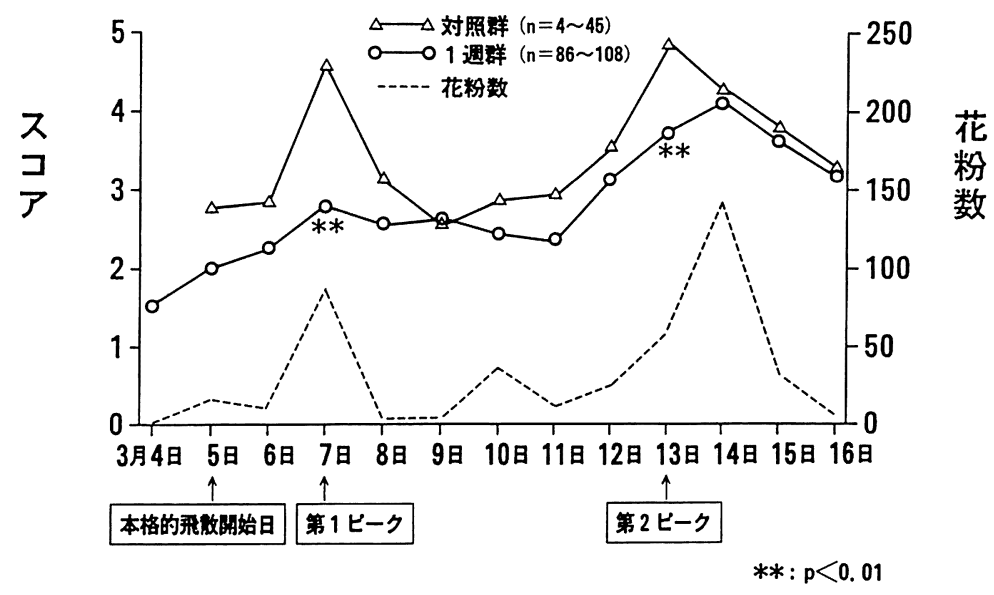

図 9 全般的鼻症状

1 週群之対照群の比較 

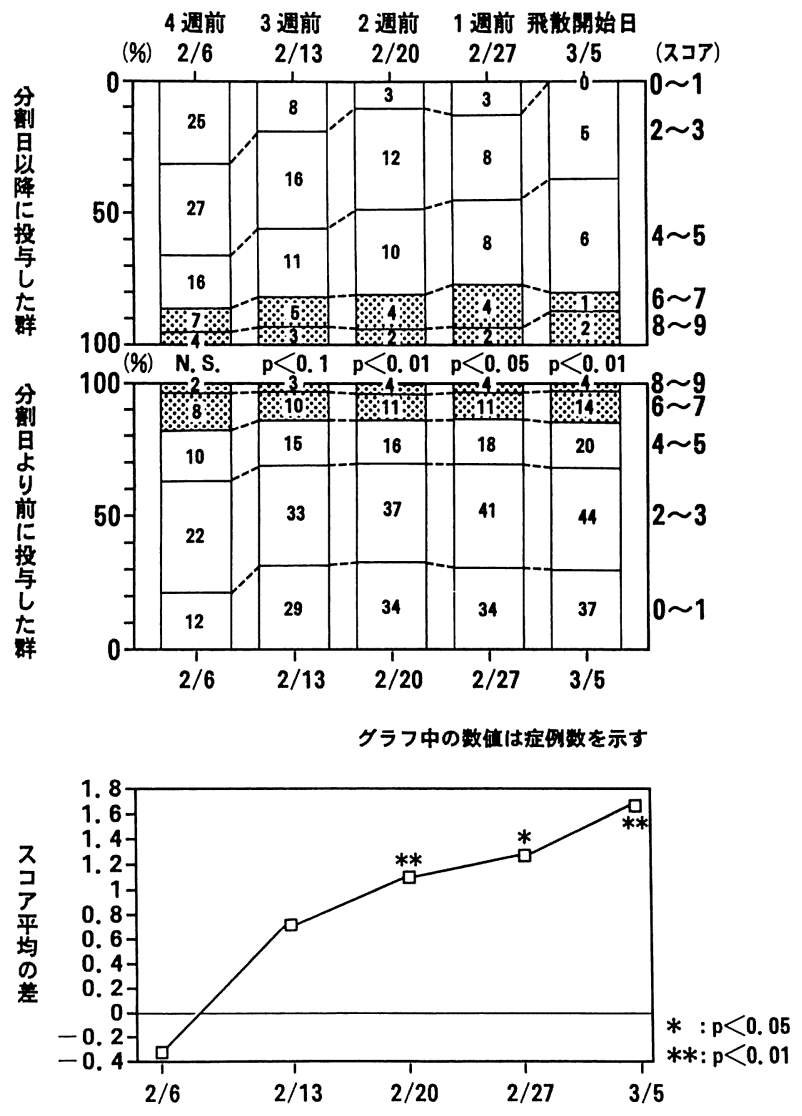

投与開始日（分割日の前後で 2 群分けて統計処理）

図10 3月 7 日(第 1 ピーク日)の全般的鼻症状

\section{考案}

スギ花粉症に対する初期治療が試みられるにつれシー ズン前期, 初期の花粉飛散の状況を示す用語の統一が急 務とされているが，現時点ではまだ用語統一がなされて いない、したがって本論文では文献引用を除いて，本検 討実施時に我々が花粉情報を作成する際に用いていた用 語を使用した。

まず，一般に予防投与と総称されるシーズン前からの 薬剤投与については，これが花粉観測と連動し原則的に 花粉飛散を確かめてから開始されたものであれば，予防 投与ではなく初期治療の充実と考えるべきではないかと， 我々が1990年に行った局所ステロイド剂によるスギ花粉 初期治療の報告1) で提唱し，以後この基準に合致するも のは初期治療と呼び予防投与とは用語的に区別している. 寸なわち，初期治療とは花粉飛散を確認後に薬物治療を 開始し，予防投与とは花粉飛散確認をせずに予定日より さかのぼって薬物治療を行うものと考えている.
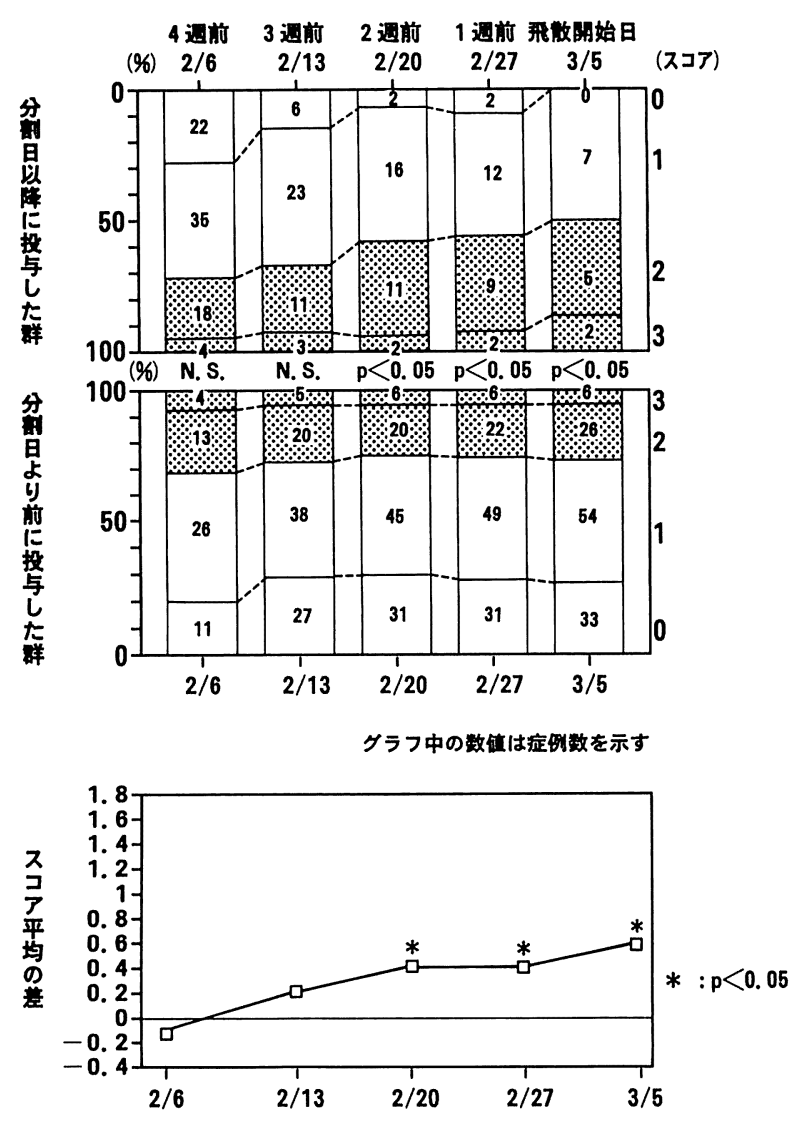

投与閒始日（分割日の前後で 2 群分けて統郙処理）

図113月 7 日(第 1 ピーク日)のくしゃみ症状

また，第 1 花粉観測日は，我々の関連施設でダーラム 型花粉捕集器によって, 最初の 1 個以上のスギ花粉を観 測した日をそれとした。 な执，本検討では京都府立医科 大学での観測を種々の解析の起点としているため 2 月 5 日を第 1 花粉観測日と図 3 に表記したが，全参加施設で は，市内関連施設のひとつで 1 月 29 日に1991年最初の 2 個の花粉が観測された ${ }^{2)}$. 本格的飛散開始日は連続して 1 個 $/ \mathrm{cm}^{2}$ 以上の花粉が飛散する日とし, ここでは 3 月 5 日となる、第 1 ピーク日，第 2 ピーク日などピーク日 の決定は，1 日100個 $/ \mathrm{cm}^{2}$ を越える日を大ピーク，30〜 99 個 $/ \mathrm{cm}^{2}$ を中ピーク，30個 $/ \mathrm{cm}^{2}$ 以下でも前後の飛散状 況から突出した飛散増加や症状増悪があれば小ピークと するという我々の基準によっている.

本格的飛散開始日や第 1 ，第 2 ピーク日あたりまでの 本格的花粉飛散開始直後の飛散パターンに限っては, 過 去の観測結果から京都, 滋賀地方に大きな地域差がない ことを既に確認している2)31. そこで図 3 に示した統計 
解析の基準となるいくつかのポイントの決定は，観測 データーの欠落のない京都府立医科大学での観測をもと に各施設の患者情報を加味して決定した.

最少有効投与開始日の検討は，少数の花粉飛散時期に 順次医療施設を訪れる患者群の内で，本格的花粉飛散が 迫った比較的遅い時期に，初期治療を開始した者への効 果を調べるものである．端的に言えば，本格的花粉飛散 のどれくらい直前までに治療を開始すれば間に合うかと いら検討であり，個々の鼻症状よりも全般的な鼻症状の 抑制を指標とした。したがって服用期間の長い 4 週群か ら認められた統計学的な有意差が，最も服用期間が短い 1 週群まで認められた点に注目すべきであろう。

これに対して，最大有効投与期間の検討は，より高い 臨床効果を求めて早期から初期治療を開始する意義を問 らものである。いたずらに服用期間を延ばすことは社会 医学的見地から問題となるが，臨床効果の程度が十分に
認められる場合は薬物療法のありかたとして意義がある と考え, 各症状について検討を加えた. 表 1 の結果総括 に示したごとく，〈しゃみを対象とするなら初期投与期 間を 2 週とするのが最善であり， 3 週以上延長してもそ れ以上の効果の増強は期待出来ないことになる. 同様に 鼻水については 3 週間の初期投与で最大の効果が得られ ると解釈出来る. 鼻閉については後述するが, 全般的鼻 症状も 2 週まで症状抑制の有意差が得られたため, 大量 飛散年度に扣けるオキサトミド初期治療の最善の投与期 間は $2 \sim 3$ 週間と結論する。ただし，鼻閉に対しては， 今回の検討からはオキサトミド初期治療の意義は見出せ なかった。この点に関しては, 我々が1990年に局所ステ ロイド剤を用いた初期治療の検討1)で鼻閉への効果が確 認されている. 花粉飛散の比較的少ない年ではあったが， 今回の検討とほぼ一致した施設, 検討法であり鼻閉を主 訴とする患者には一つの選択肢ともいえる.
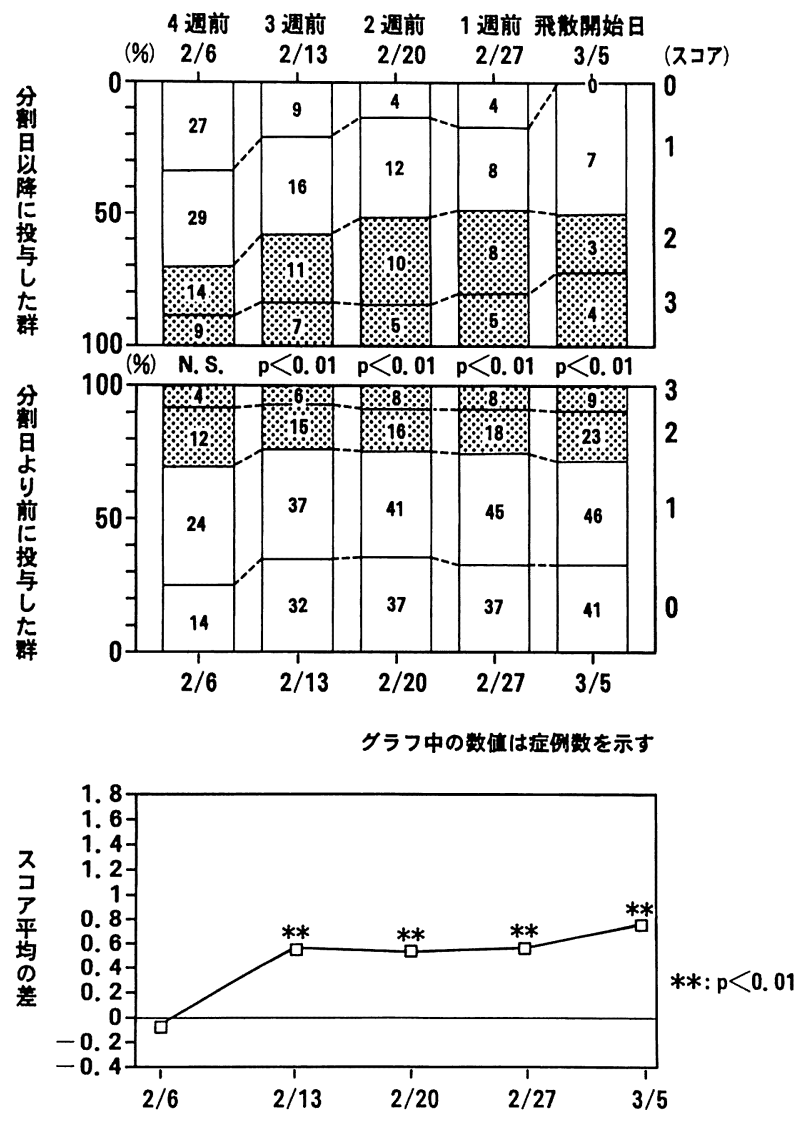

投与開始日（分割日の前後で 2 群分けて統計処理）

図123月 7 日(第 1 ピーク日)の番水症状
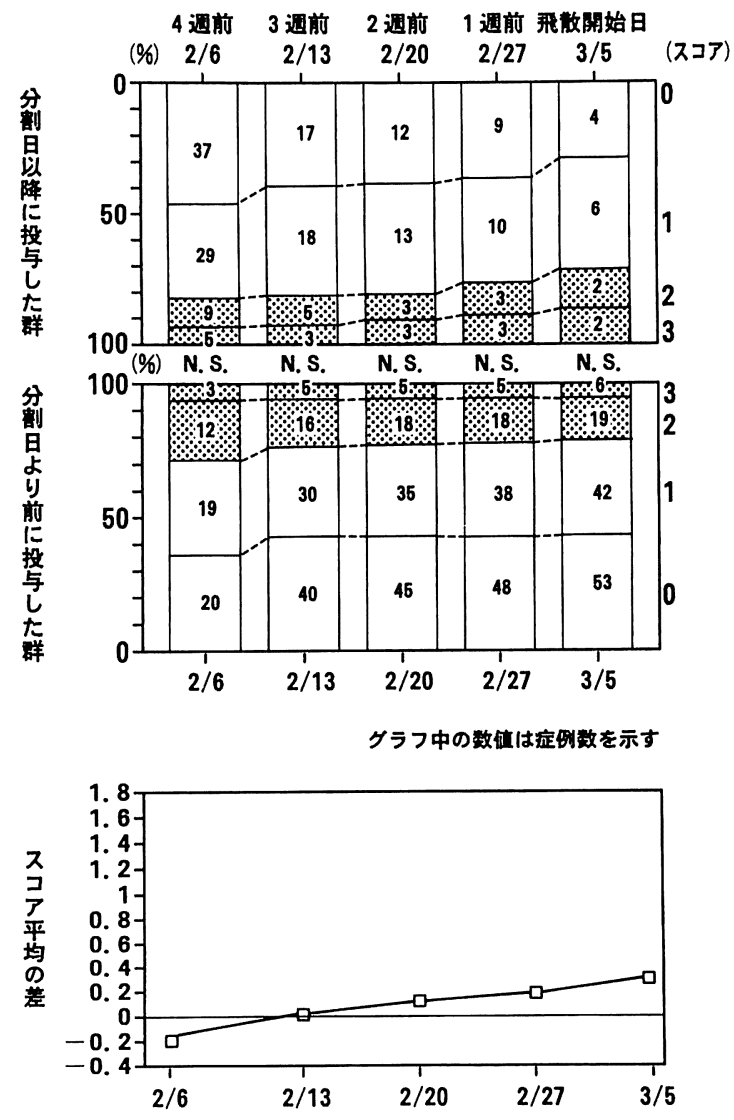

投与開始日（分割日の前後で 2 群分けて統計処理）

図13 3 月 7 日(第 1 ピーク日)の鼻閉症状 
すでにスギ花粉症に対するケミカルメディエーター遊 離抑制剂の効果については諸家の報告がある．実施年度 の花粉飛散量や薬理作用の違いもあり，一概に比較は出 来ないが，本検討で用いたオキサトミドと近似の薬理作 用を持ついわゆる塩基性抗アレルギー剂を用い，我々と 同時期すなわち全国的に中等量から大量のスギ花粉飛散 に見まわれた，1991年に実施されたいくつかの報告を引 用する。

豊島ら4)による，塩酸アゼラスチンを用いた仙台市を 中心とした東北地方の検討では，予防投与群が発症後投 与群に比して飛散初期の 4 つ目のピークまでの観察で, 自覚症状平均点推移が低く, ピークの幾つかで統計学的 有意差が認められたとしている。また予防投与群を投与 期間別に 2 週未満, 2 週以上 4 週未満, 4 週以上の 3 群 に分け群間比較した結果，大量飛散年度ではアゼラスチ ンでは 4 週間以上の季節前投与が有効と結論している.
金谷ら5゙とよる，同じく塩酸アゼラスチンを用いた山 口県地方の検討では, 服用 2 週間以内の飛散初期投与群 と飛散中投与群の間には, 治療効果の上で有意差は得ら れなかった，その考案の一つに，予防投与の効果出現時 期一致して極めて大量の花粉飛散に見まわれたとする点 が薬物治療の限界を示唆するものとして興味深い。

水田ら6にとる，Terfenadinを用いた岐阜県下 2 地 点の検討では，予防投与期間平均 4.2 週， 2.7 週の $2 つ の$ 観察地域の総合した成績で，予防投与例は花粉飛散後に 投与を開始した症例に比して，花粉飛散経過中の鼻症状 が抑制され，ピーク時の鼻症状は鼻汁以外は有意差を認 めないものの症状期間を短縮されることをあきらかにし ている。

藤田ら7)による，同じくTerfenadin を用いた弘前市 での検討では，飛散前投与と飛散後投与では，オープン トライアルでもあり統計的有意差までは言及していない
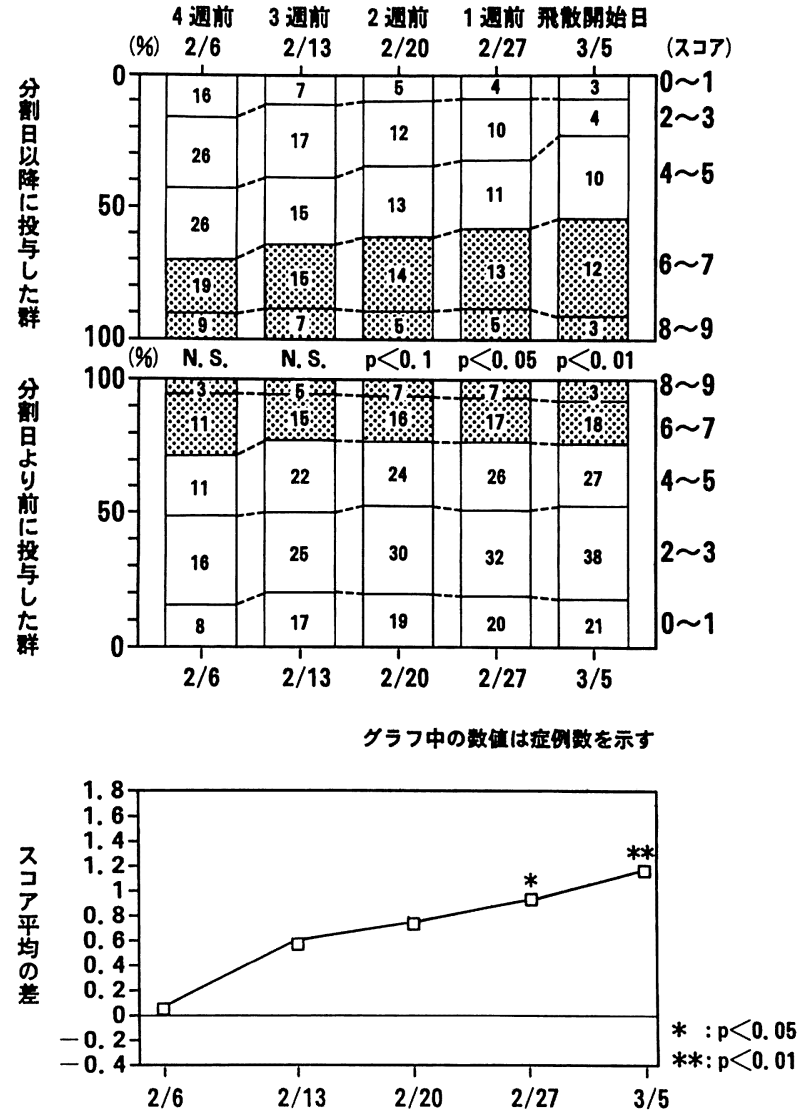

投与開始日（分割日の前後で 2 群分けて統計処理）

図143月13日（第 2 ピーク日）の全般的鼻症状
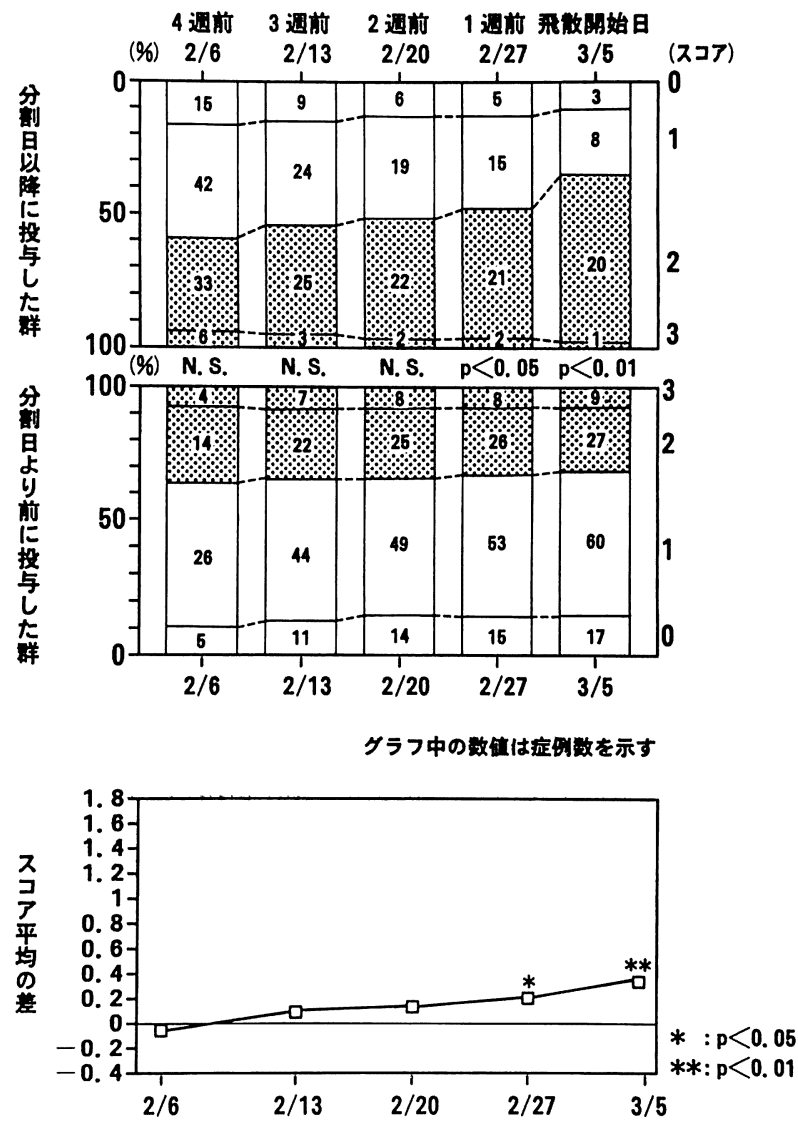

投与開始日（分割日の前後で 2 群分けて統計処理）

図153月13日(第 2 ピーク日)のくしゃみ症状 
が，飛散前投与のほらがやや優れた効果を認めたと結論 している.

1991年の京都府立医科大学でのスギ花粉飛散総数は

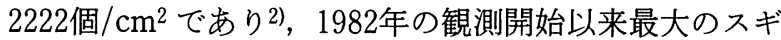
花粉飛散を記録した．同年は前述の 4 地域に执いてもス ギ花粉の大量飛散年度であり，薬物治療の効果や限界を

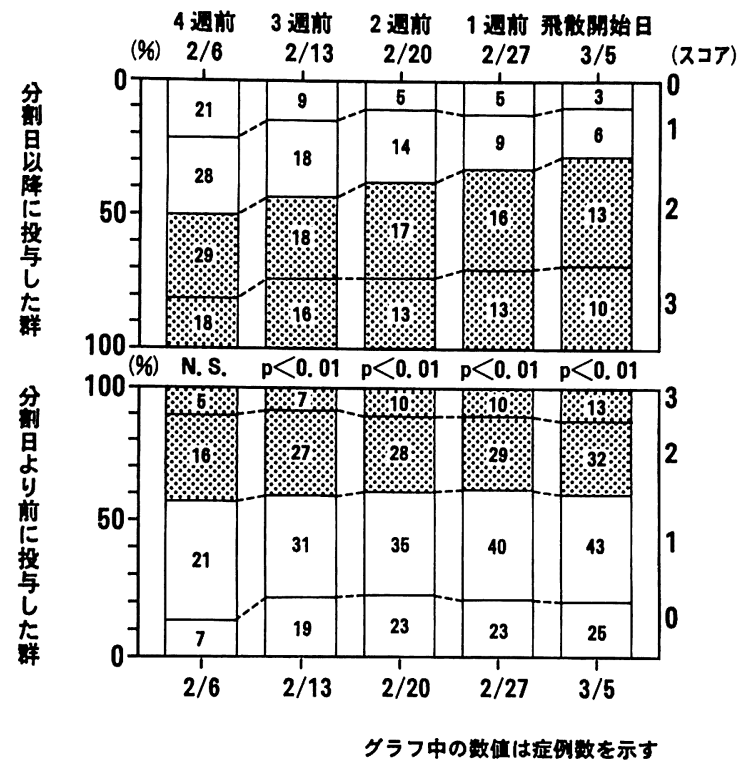

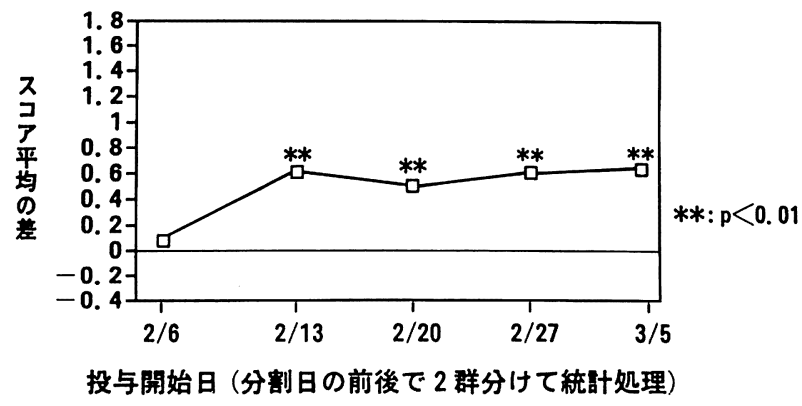

図163月13日(第 2 ピーク日)の番水症状
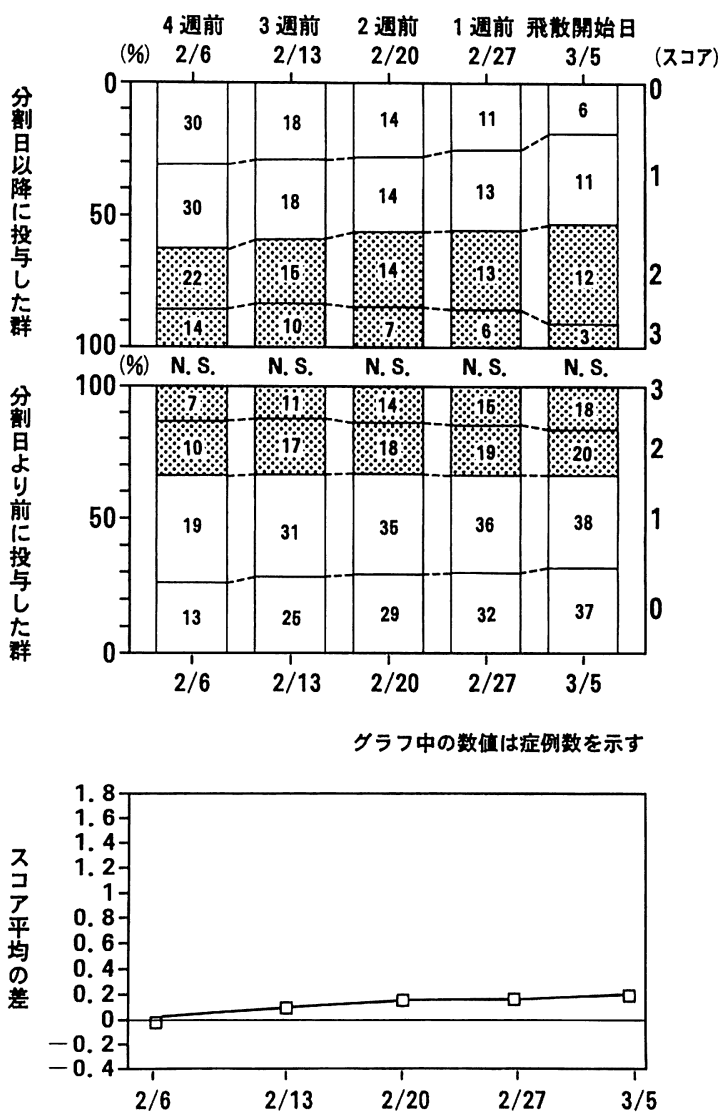

投与開始日（分割日の前後で 2 群分けて統計処理）

図173 月13日(第 2 ピーク日)の鼻閉症状

表 1 最大有効投与期間の検討集計

飛散第 1 ピーク日の有意差検定（3 月 7 日）

\begin{tabular}{|c|c|c|c|c|c|}
\hline $\begin{array}{l}\text { 分割日 } \\
\text { 服用期間 }\end{array}$ & $\begin{array}{l}2 / 6 \\
4 \text { 週前 }\end{array}$ & $\begin{array}{l}2 / 13 \\
3 \text { 週前 }\end{array}$ & $\begin{array}{l}2 / 20 \\
2 \text { 週前 }\end{array}$ & $\begin{array}{l}2 / 27 \\
1 \text { 用前 }\end{array}$ & $\begin{array}{l}3 / 5 \\
0 \text { 週前 }\end{array}$ \\
\hline 全般的鼻症状 & - & - & $* *$ & $* *$ & $* *$ \\
\hline くしゃみ & - & - & * & * & * \\
\hline 鼻水 & - & $* *$ & $* *$ & $* *$ & $* *$ \\
\hline 奥閉 & - & - & - & - & - \\
\hline
\end{tabular}

飛散第 2 ピーク日の有意差検定（3 月13日）

\begin{tabular}{|c|c|c|c|c|c|}
\hline $\begin{array}{l}\text { 分割日 } \\
\text { 服用期間 }\end{array}$ & $\begin{array}{l}2 / 6 \\
4 \text { 週前 }\end{array}$ & $\begin{array}{l}2 / 13 \\
3 \text { 週前 }\end{array}$ & $\begin{array}{l}2 / 20 \\
2 \text { 週前 }\end{array}$ & $\begin{array}{l}2 / 27 \\
1 \text { 週前 }\end{array}$ & $\begin{array}{l}3 / 5 \\
0 \text { 週前 }\end{array}$ \\
\hline 全般的鼻症状 & - & - & $* *$ & * & $* *$ \\
\hline くしゃみ & - & - & - & $*$ & $* *$ \\
\hline 睤水 & - & $* *$ & $* *$ & $* *$ & $* *$ \\
\hline 鼻閉 & - & - & - & - & - \\
\hline
\end{tabular}


見極めるには適切なシーズンであったといえる．前述の ごとくいわゆる塩基性抗アレルギー剤を用いた同年度の 検討でも, 評価には若干の差異がみられるが, 総括的に は大量飛散年度に损いても $2 \sim 3$ 週の薬物治療で, 飛散 ピーク時の症状緩和が期待出来るものと解釈寸る．ただ し金谷らの山口県での検討の如く5), 初期治療の効果出 現時期に一致して400個を越える花粉飛散に見舞われる と，その効果も相殺されることになろう.

スギ花粉症に対する初期治療が，本格的飛散開始後の 症状緩和に有効な点は既に多くの認める所であり, 今後 もしばらくはスギ花粉症治療の中でも大きな比重を占め ることは予想に難くない。

ただし，スギ花粉症に対する初期治療は，それを行う 地域の花粉観測と密接に連携した上で, 初めて成立する ものであろう．花粉観測を有効な花粉情報とするために はいくつかの因子があるが，今後は受け手の利用のしか たまで考立た情報の作成が必要となろう8)。また，情報 提供先も一般向けだけではなく, 医療施設, 行政関係な ど多岐にわたってくる9．ここでは，本論文と関連の深 い，実際に薬物治療を括こなら実地医家に対する情報伝 達について我々の見解を述べる.

実地医家は，そのシーズンの花粉飛散状況を事前に把 握し適切な処方計画をたて, 花粉情報提供施設はこの目 的の添らような情報提供を積極的に行ら必要がある。初 期治療を行ら実地医家にとって必要なものは, マスメデ ィアを通じた一般向けの花粉情報ではなく, 飛散に先行 した花粉情報や該当地域の飛散の実際であろう。このた めに我々は，1990年より京都府医師会を通じて府医師会 員を対象とした医家向け花粉情報の提供を行ってき

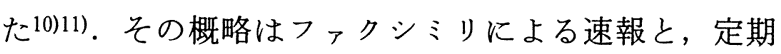
刊行誌での中期予報, 地域ごとの花粉数, 患者数, 症状 スコアの実際などである. 開始初年度と 4 年後に行った アンケート調査では, 実地医家が求めるものは, 飛散開 始時期の予報と, 飛散ピークの予報が 1 位, 3 位 ${ }^{10)}, 1$ 位, 2 位 ${ }^{11)}$ 占め, 治療への反映の時期がうかがい知 れる. 今後, スギ花粉症初期治療を社会医学的にも確立 したものにするためには，花粉観測施設は実地医家に対 する情報提供を積極的に行う必要がある点を最後に強調 したい.

$$
\text { まとめ }
$$

1.オキサトミド剤による, スギ花粉症初期治療の最
善の服用期間について検討した.

2. 本格的飛散開始の 4 週間前から 1 週前までに服用 開始した 4 群すべてに，飛散開始後服用群との有意差が 見られたため，最少有効投与開始日は 1 週間とした。

3. 全般的鼻症状改善度, くしゃみについては 2 週間, 鼻水については 3 週間まで服用期間を延長する意義が確 認された。鼻閉については服用期間を延長する意義は認 めなかった。

4.以上より，オキサトミド剤によるスギ花粉症初期 治療の最善の服用期間は，本格的花粉飛散前 $2 \sim 3$ 週間 と結論した.

5. スギ花粉症初期治療実施に打いては, 花粉観測施 設と実地医家の連係が重要である。

本論文の主旨は第 4 回日本アレルギー学会春季臨床集会 (1992年 4 月, 横浜市)においてロ演した.

\section{参考文献}

1）水越文和, 竹中 洋, 出島健司, 他：リノコート®による スギ花粉症初期治療. 耳鼻臨床 $84: 1179 \sim 1188,1991$.

2 ) 出島健司, 竹中 洋, 齊藤憲治, 他 : スギ花粉症の発症と 花粉飛散についての検討. アレルギー 41: 1405 1411, 1992.

3 ）水越文和：京滋地方の花粉症の地域特性. アレルギーの臨 床 $13: 38 \sim 40,1993$.

4 ）豊島 勝, 柴原義博, 稲村直樹, 他：スギ花粉症に対する 塩酸アゼラスチンの予防効果. 耳展 34 補 $8: 655 \sim 671$, 1991.

$5 ）$ 金谷浩一郎，関谷 透，沖中芳彦，他：スギ花粉症に対す る塩酸アゼラスチンの臨床評価 一投与開始時期からみた 効果一. 耳展 $36: 90 \sim 98,1993$.

6 ）水田啓介, 山田剛寬, 山田匡彦, 他 : スギ花粉症に対する トリルダン®の予防効果. 耳鼻臨床 $85: 1163 \sim 1171,1992$.

7 ) 藤田猛志, 朴沢二郎, 新川秀一, 他 : スギ花粉症に対する トリルダン®の臨床成績. 耳鼻臨床 $86: 135 \sim 141,1993$.

8 ）竹中 洋, 高木伸夫, 齊藤憲治, 他: 花粉情報を活用した 花粉症予防対策. JOHNS $10: 393 \sim 397,1994$.

9）齊藤憲治 : スギ花粉予報, co-medical mass と医者の役目, 患者からみた予報のとら省かた，日鼻会誌 $31 ： 143 〜 144$, 1993.

10）水越文和, 竹中 洋, 出島健司, 他: 今年度実施した医家 向夗花粉情報. 京都医学会誌 $38: 25 \sim 29,1990$.

11）竹中 洋, 高木伸夫, 水越文和, 他: 京都府花粉情報セン ター医家向け花粉情報について. 京都医学会誌 $41: 45 \sim 51$, 1994.

(別刷請求先 : 水越文和 $\left(\begin{array}{l}\text { \%602 京都市上京区河原町通広小路上ル暒井町 } 465 \\ \text { 京都府立医科大学耳鼻咽喉科学教室 }\end{array}\right)$ 